\title{
Validation of suitable reference genes for quantitative real-time PCR normalization in Crassostrea gigas spat stage during toxic dinoflagellates exposure
}

\author{
Validación de genes de referencia adecuados para la normalización de PCR cuantitativa en tiempo real \\ de juveniles de Crassostrea gigas expuestos a dinoflagelados tóxicos
}

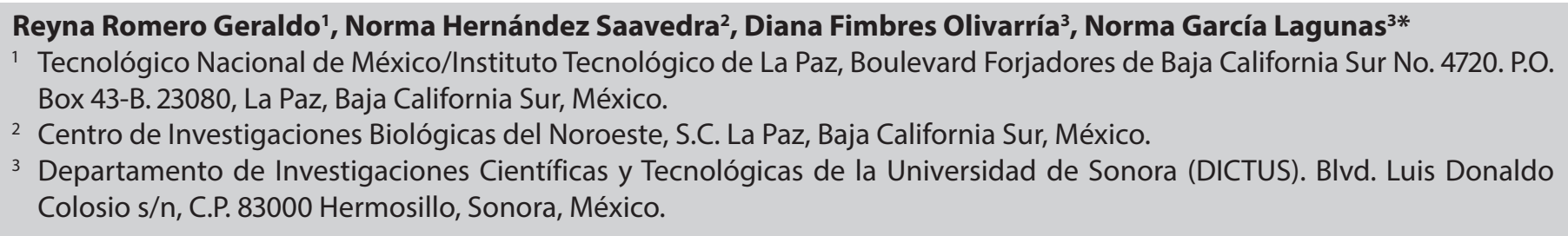

\section{ABSTRACT}

The quantitative real-time polymerase chain reaction is a widely used method for gene expression analysis requiring carefully selected reference genes to ensure data validity. Regardless of several studies on gene expression bivalves and particularly Crassostrea gigas, has not been fully investigated regarding the evaluation of reference genes suitable for normalization of expression analysis. In this study, five candidate reference genes: actin, $\beta$ tubulin, a subunit of elongation factor 1, glyceraldehyde-3-phosphate dehydrogenase and $28 \mathrm{~S}$ ribosomal RNA were analyzed, to determine the most suitable reference genes, after of Crassostrea gigas spat were fed with Gymnodinium catenatum and Prorocentrum lima in mixed and compared to non-toxic diet Isochrysis galbana. The results showed that $\beta$-tub and ef- 1 a were the most stable genes for oysters feed with a mixed diet of P. lima and I. galbana. The gapdh and $28 \mathrm{~S}$ rRNA were the most stable genes for oysters feed with G. catenatum and I. galbana. In addition, the selection of optimal reference genes during dinoflagellates exposure was verified by analyzing the expression level of trypsin and cytochrome c oxidase I target genes. Our study could be beneficial for future studies on gene expression in C. gigas.

Keywords: Gene expression, reference gene, normalization, toxic dinoflagellates, Crassostrea gigas

\section{RESUMEN}

La reacción en cadena de la polimerasa cuantitativa en tiempo real es un método ampliamente utilizado para el análisis de expresión génica, requiere genes de referencia cuidadosamente seleccionados para garantizar la validez de los datos. A pesar de los estudios sobre expresión génica en bivalvos y particularmente en Crassostrea gigas, existe escasa información sobre la evaluación de los genes de referencia adecuados para la normalización del análisis de expresión. En este estudio se analizaron cinco genes candidatos de referencia: actina, $\beta$ tubulina, subunidad a del factor de elongación 1, gliceraldehído-3-fosfato deshidrogenasa y ARN ribosomal 28S, para determinar los genes más adecuados, en juveniles de Crassostrea gigas alimentado con una dieta mixta de Gymnodinium catenatum y Prorocentrum lima en comparación con una dieta no tóxica de Isochrysis galbana. Los resultados mostraron que $\beta$ tub y ef1 a fueron los genes más estables para C. gigas alimentado con una dieta mixta de l. galbana y $P$. lima; los genes más estables para los ostiones alimentados con I. galbana y G. catenatum fueron gapdh y $28 S$ rRNA. Además, la selección de los genes de referencia durante la exposición a dinoflagelados tóxicos se verificó analizando el nivel de expresión de los genes blanco tripsina y citocromo c oxidasa I. El presente estudio será de gran utilidad para futuros estudios sobre análisis de expresión génica en juveniles de C. gigas.

Palabras clave: Expresión génica, genes de referencia, normalización, dinoflagelados tóxicos, Crassostrea gigas

\section{INTRODUCTION}

Mollusks aquaculture has significant economic importance worldwide and the Pacific oyster Crassostrea gigas is one of the most cultured oysters (Shumway, 1990). Recently, the research of $C$. gigas has been increased in topics such as immunology, genetics, genomics and hybrid tolerability (Saavedra and Bachére, 2006; Dheilly et al., 2011; Yan et al., 2017). The Pacific oyster could be exposed to bacterial, protozoan, and viral pathogens, as well as to abiotic agents such as xenobiotics, and marine toxins (Helm, 2004). Due to the stress caused by all these agents, there has been an increase in the research to study the changes of gene expression in oysters by quantitative reverse transcription polymerase chain reaction ( $q R T-P C R$ ). Quantitative $P C R$ is a sensitive, specific and reproducible method to study gene expression (Bustin et al., 2005). For relative quantification is required some reference gene as the internal control, for example, actin and tubulin, though their expression before and after a challenge has been scarcely investigated (Dheda et al., 2005). Therefore, it is necessary to obtain information about the selection of reference genes to study gene stability in different experimental conditions.

*Autor para correspondencia: Norma García Lagunas Correo electrónico: norma.lagunas@unison.mx

Recibido: 9 de octubre de 2019 Aceptado: 18 de diciembre de 2019 
The Pfaffl method uses the $\mathrm{Ct}\left(2^{\Delta \Delta c t}\right)$ to determine the gene expression level in distinct conditions considering the amplification efficiency adjustment (Pfaffl et al., 2004). An essential component of the relative quantification of gene expression is the reference gene (internal control or housekeeping gene) that is used to correct the effect of experimental fluctuations, e.g., nucleic acid concentration, instrumental errors (Bustin, 2010).

Genomic studies allow a better understanding of the cellular response and specific metabolic pathways involved in response to the ingestion of the toxic dinoflagellate cells. It was necessary to determine the stability of possible reference genes for profiling the $C$. gigas spat gene expression on the experimental conditions tested.

In this work, transcriptional changes of five reference genes in C. gigas fed with toxic dinoflagellates $G$. catenatum and $P$. lima compared to a non-toxic diet of I. galbana were evaluated. The expression changes of the candidate genes were analyzed by three normalization algorithms: Bestkeeper (Pfaffl et al., 2004), GeNorm (Vandesompele et al., 2002; Bustin, 2010) and NormFinder (Andersen et al., 2004). These algorithms ranked reference genes according to their stability expression. Finally, we corroborate the validation of optimal reference genes by analyzing the relative expression of two target genes, trypsin and cytochrome coxidase l, under the experimental conditions tested in C. gigas spat stage.

\section{MATERIALS AND METHODS Microalgae culture}

In this study, the planktonic dinoflagellate Gymnodinium catenatum (strain GCCV6), a producer of paralyzing shellfish toxins (PST) (Kodama, 2010) was utilized, as well as, the epibenthic dinoflagellate $P$. lima (strain PRL-1) a producer of diarrheic toxins (DSP) (Núñez-Vázquez et al., 2003). Strains were obtained from the CIBNOR Collection of Marine Dinoflagellates, and grown in Fernbach flasks with $\mathrm{f} / 2$ medium (Guillard, 1975) enriched with selenium. The culture medium was prepared using seawater (salinity $35 \mathrm{~g} \mathrm{~L}-1$ ) filtered with $0.45 \mu \mathrm{m}$ membrane and sterilized at $121^{\circ} \mathrm{C}, 15 \mathrm{lb}$ for $15 \mathrm{~min}$. Cells were kept at proliferating conditions of $22^{\circ} \mathrm{C} \pm 1{ }^{\circ} \mathrm{C}$, continuous light of $150 \mu \mathrm{mol}$ photons $\mathrm{m}^{-2} \mathrm{~s}^{-1}$ light intensity. For experiments, dinoflagellate cells were harvested by centrifugation ( $2500 \times \mathrm{g} 10 \mathrm{~min}^{-1}$ ) during the late exponential growth phase (19 days after inoculation), and cell density was adjusted using cell counting data on Sedgwick-Rafter slides (Microscope Olympus BX41, Tokyo, Japan) after sample fixation with Lugol's solution (Gifford and Caron, 2000).

The microalgae I. galbana strain ISG-1 was obtained from the Live Food Laboratory at CIBNOR and used as a negative control or non-toxic diet. Cell concentrations in feeding experiments were determined by the Neubauer chamber ( $0.1 \mathrm{~mm}$ in depth) after fixation with Lugol's solution with an optical microscope.

\section{Oysters culture}

C. gigas juvenile individuals $(3 \pm 1 \mathrm{~mm}, 0.022 \pm 0.008$ g) were obtained from the hatchery "Acuacultura Robles" at Las Botellas (Bahía Magdalena), Baja California Sur, Mexico. For acclimatization, organisms were divided into groups and kept in plastic aquariums $(10 \mathrm{~L})$ with aerated filtered seawater $(0.22 \mu \mathrm{m})$ at $21^{\circ} \mathrm{C}$ at and $34 \mathrm{~g} \mathrm{~L}$ for ten days. The maintenance diet consisted of bacteria-free I. galbana (ISG-1) at $7.5 \times 10^{5}$ cells $\mathrm{mL}^{-1}$.

\section{Experimental design and sample collection}

The number of dinoflagellate cells was calculated based on G. catenatum (Band-Schmitd et al., 2005) and P. lima (Hallegraeff, 1995) harmful algal blooms (HABs) and reports on their toxic effects. The experiments consisted of three diet treatments separated in two experimental conditions and non-toxic control diet; condition 1: oysters fed with an algal mix of $P$. lima $\left(3 \times 10^{3}\right.$ cell $\left.\mathrm{mL}^{-1}\right)$ and I. galbana $\left(7.5 \times 10^{5}\right.$ cell $\mathrm{mL}^{-}$ $\left.{ }^{1}\right)$; condition 2: oysters fed with an algal mix of $G$. catenatum (3 $\times 10^{3}$ cell $\left.\mathrm{mL}^{-1}\right)$ and I. galbana $\left(7.5 \times 10^{5}\right.$ cell $\left.\mathrm{mL}^{-1}\right)$. These diets were compared with a non-toxic control diet consisting of oysters fed with I. galbana alone $\left(7.5 \times 10^{5}\right.$ cell $\left.\mathrm{mL}^{-1}\right)$. The experimental groups of $C$. gigas were distributed as described previously (García-Lagunas et al., 2013). Briefly, groups of 25 oysters (in triplicate) were maintained in $100 \mathrm{~mL}$ transparent polypropylene containers with a 1:1 the microalgal mixture in a final volume of $50 \mathrm{~mL}$. At 7- and 14-days post-challenge, five organisms of each experimental unit were randomly sampled. The sampled organisms corresponding to each sample time were replaced on each experimental unit by oysters exposed in the same experimental conditions (mirror exposure units used for replacement only). Samples were washed with sterile seawater and finally frozen at $-80^{\circ} \mathrm{C}$ until use.

\section{Total RNA preparation and first-strand cDNA synthesis}

Total RNA was extracted from $30 \mathrm{mg}$ per the whole body of oysters spat in pools of five, with TRIzol ${ }^{\circ}$ Reagent (Life Technologies, Carlsbad, California) according to the manufacturers' protocol. After homogenization, each sample was subjected to two TRIzol ${ }^{\circledR}$ extractions. The concentration and purity of RNA were determined by measuring the absorbance at $260 \mathrm{~nm}$ in an ND-2000 spectrophotometer (Thermo Scientific, U.S.A). The RNA integrity was analyzed on $1 \%(\mathrm{w} / \mathrm{v})$ agarose gel. To ensure complete DNA absence, a direct PCR was performed using $2 \mu \mathrm{L}$ (100 ng) of each RNA preparation with $28 \mathrm{~S}$ ribosomal specific primers as a non-amplified control. After each verified RNA sample, 0.5 $\mu \mathrm{g}$ was used for cDNA synthesis using the SuperScript ${ }^{\mathrm{TM}}$ III First-Strand Synthesis System SuperMix ${ }^{\circledR}$ (Life Technologies, Carlsbad, California). Total RNA was reverse-transcribed by oligo-dT, and the resulting CDNA was stored at $-80^{\circ} \mathrm{C}$ until use. Control reactions were performed with no cDNA template or with non-reverse transcribed RNA to determine the level of background DNA contamination after DNAase I treatment. No DNA contamination was detected.

Volumen XXII, Número 2 


\section{Primer design and PCR efficiency}

Five reference genes, actin (act), $\beta$ tubulin ( $\beta$-tub), a subunit of elongation factor 1 (ef-1a), glyceraldehyde-3-phosphate dehydrogenase (gapdh), and 285 ribosomal RNA ( $28 \mathrm{~S}$ $r R N A$ ) were examined for their $\mathrm{QPCR}$ reference potential in the gene expression study in Pacific oysters exposed to dinoflagellates. The primers used to amplify these five genes (Table 1) were designed based on C. gigas genome sequences (Genebank, http://www.ncbi.nlm.nih.gov). The primer sequences were assessed for dimer and hairpin formation using RNA fold WebServer (http://rna.tbi.univie.ac.at/cgi-bin/ RNAfold.cgi).

To test the primer efficiency $(E)$, the standard curve method was used. For that, five-fold serial dilutions of CDNA of oysters exposed to dinoflagellates and control were subjected to standard qPCR protocol. Threshold $\mathrm{Ct}$ values and the logarithm of the target concentrations were plotted to calculate the slopes of the standard curves (Table 1). The amplification efficiency of qPCR was calculated using the equation: $E=10\left[^{-1 / \text { slope }}-1 \times 100\right)$, the acceptable $E$ value was defined as between 95 and $100 \%$ (Bustin, 2002).

Additionally, a validation analysis of candidate reference gene stability was performed for carefully selecting them to ensure data reliability. The data of $\mathrm{Ct}$ values were used to perform GeNorm, NormFinder and BestKeeper analysis.

\section{Reference Gene Validation}

The $\mathrm{QPCR}$ reactions were conducted in triplicate in holding Strip Tubes (0.1 mL) (Qiagen, Hilden, Germany), using a Rotor gene 6000 Real-Time PCR detection system (Qiagen, Hilden, Germany). A qPCR cocktail-mix was prepared with $2.5 \mathrm{mM} \mathrm{MgCl}, 2 \mathrm{mM}$ dNTP (each), $0.3 \mathrm{U}$ of Platinum Taq polymerase (Invitrogen), 10 picomoles of each primer pair, and 20X EvaGreen fluorescent dye Biotium ${ }^{\oplus}$, and $3.2 \mathrm{ng} / \mu \mathrm{L}$ of CDNA in a final volume of $15 \mu \mathrm{L}$. Amplification conditions were: $95^{\circ} \mathrm{C}$ for $5 \mathrm{~min} ; 40$ cycles of $95^{\circ} \mathrm{C}(60 \mathrm{~s}), 61^{\circ} \mathrm{C}(30 \mathrm{~s})$ and $72^{\circ} \mathrm{C}(5 \mathrm{~s})$, acquiring the fluorescence at $79^{\circ} \mathrm{C}(1 \mathrm{~s})$; finally a dissociation step from $65^{\circ} \mathrm{C}$ to $95^{\circ} \mathrm{C}\left(1{ }^{\circ} \mathrm{C} / \mathrm{s}\right)$ was done. For each candidate reference gene, the melt curve and gel picture were analyzed to verify the specificity of the amplified products and to confirm that at a single PCR product had been amplified. Amplification efficiencies were used for gene stability analyses of the potential set of reference genes (Table 1).

\section{Statistical analysis}

For GeNorm ${ }^{\text {TM }}$ (Vandesompele et al., 2002; Pfaffl et al., 2004; Andersen et al., 2004) NormFinder and BestKeeper analysis the $\mathrm{Ct}$ were transformed to relative quantities using the formula (1+E- $\Delta$ cq) (Livak and Schmittgen 2001). Ct values were transformed into a natural logarithm to analysis on NormFinder. No transformed $\mathrm{Ct}$ values are required for BestKeeper analysis.

The GeNorm algorithm first calculates an expression stability value $(\mathrm{M})$ for each gene and then compares the pair-wise variation $(V)$ of this gene with the others. Pairwise variation $(V)$ between two sequential normalization factors containing an increasing number of genes (Vandesompele et al., 2002). NormFinder identifies stably expressed genes among a set of candidate normalization genes. The analysis produces a stability value for the examined genes, which is the variation calculation of the expression of the genes under different experimental conditions (Andersen et al., 2004). BestKeeper's index calculates the geometric mean of those genes that are expressed with a standard deviation (SD) lower than 1 (Pfaffl et al., 2004). The web tool RefFinder (https:// omictools.com/reffinder-tool) evaluates the gene rank from

Table 1. Primer sequences, gene name, expected amplicon size, and efficiency corresponding to reference genes and target gene (tryp and coi) from Crassostrea gigas.

Tabla 1. Secuencias de oligonucleótidos, nombre del gen, tamaño esperado del amplicón y eficiencia, correspondiente a los genes de referencia y a los genes blanco (tryp y coi) de Crassostrea gigas.

\begin{tabular}{|c|c|c|c|c|c|c|c|}
\hline Primers & Sequence $5^{\prime}-3^{\prime}$ & Gene name & $\begin{array}{l}\text { Amplicon } \\
\text { (pb) }\end{array}$ & $\begin{array}{c}\text { PCR } \\
\text { Efficiency }\end{array}$ & $\mathbf{R}^{2}$ & $\begin{array}{l}\text { Genbank } \\
\text { access } \\
\text { number }\end{array}$ & $\begin{array}{l}\text { Gene } \\
\text { function }\end{array}$ \\
\hline $\begin{array}{l}\mathrm{Cg}-28 s-\mathrm{Fw} \\
\mathrm{Cg}-28 s-\mathrm{Rv}\end{array}$ & $\begin{array}{l}\text { GGAGTCGGGTTGTTTGAGAATGC } \\
\text { GTTCTTTTCAACTTTCCCTCACGG }\end{array}$ & $\begin{array}{l}\text { Ribosomal } \\
\text { subunit 28s }\end{array}$ & 114 & 1.97 & 0.99 & AY632555 & Protein Ribosomal \\
\hline $\begin{array}{l}\text { Cg-gapdh-Fw } \\
\text { Cg-gapdh-Rv }\end{array}$ & $\begin{array}{l}\text { GTTCAAATATGATTCAACTCACGG } \\
\text { TGGATCCCGTTCGCAATATACG }\end{array}$ & $\begin{array}{c}\text { Glyceraldehyde } 3 \\
\text { phosphate } \\
\text { dehydrogenase }\end{array}$ & 109 & 2.0 & 0.99 & AJ544886 & Catalyzation in glycolycosis \\
\hline $\begin{array}{l}\text { Cg-tub } \beta-F w \\
\text { Cg-tub } \beta-R v\end{array}$ & $\begin{array}{l}\text { AGCAGATGTCGTAGAGAGCTTC } \\
\text { TGAACACATTCTCCGTTGTCCC }\end{array}$ & Tubulin $\beta$ & 144 & 1.96 & 0.99 & CB617442 & $\begin{array}{l}\text { Microtubule component of } \\
\text { the eukaryotic cytoskeleton }\end{array}$ \\
\hline $\begin{array}{l}\mathrm{Cg}-a c t-\mathrm{Fw} \\
\mathrm{Cg}-a c t-\mathrm{Rv}\end{array}$ & $\begin{array}{l}\text { TACTCTTTCACCACCACAGCCG } \\
\text { TAGAGATGAGGATGAAGCAGCAG }\end{array}$ & $\operatorname{Actin}(G \mid A)$ & 117 & 1.95 & 0.98 & AF026063 & $\begin{array}{c}\text { Cell motility, structure, and } \\
\text { integrity }\end{array}$ \\
\hline $\begin{array}{l}\text { Cg-ef-1a-Fw } \\
\text { Cg-ef-1a-Rv }\end{array}$ & $\begin{array}{l}\text { ACCATACAGTGAGGCTCGATTC } \\
\text { GTGGAAGCCTCAATCATGTTATC }\end{array}$ & $\begin{array}{l}\text { Elongation } \\
\text { factor1-a }\end{array}$ & 138 & 2.0 & 0.98 & AB122066 & Transcription factor \\
\hline $\begin{array}{l}\text { Cg-tryp Fw } \\
\text { Cg-tryp Rv }\end{array}$ & $\begin{array}{l}\text { GCCAGTGACGTAAGACAACTCG } \\
\text { CAACCATCAACAACGACATTGCC }\end{array}$ & Trypsin & 125 & 2.0 & 0.99 & CB617494 & Protein metabolism \\
\hline $\begin{array}{l}\mathrm{Cg}-\mathrm{coi} \mathrm{Fw} \\
\mathrm{Cg}-\mathrm{coi} \mathrm{Rv}\end{array}$ & $\begin{array}{l}\text { GTGTATGTCCTTATTCTTCCAGG } \\
\text { GCACGCGTATCAATATCCATTCC }\end{array}$ & $\begin{array}{l}\text { cytochromec } \\
\text { oxidase I }\end{array}$ & 182 & 1.98 & 0.98 & AB033687 & Oxidative Metabolism \\
\hline
\end{tabular}


each program. The value assigned in RefFinder for each gene is used to calculate the geometric mean of their values for the overall final ranking. Thus, the lower value is assigned to the gene with more stable expression.

The $2^{-\Delta \Delta C T}$ method (Rozen et al., 2000; Bustin 2002) was used to normalize the relative expression of target genes trypsin (tryp) and cytochrome c oxidase (coi). The negative control non-toxic was used as the reference sample (calibrator). The statistic difference in gene expression was analyzed by one-way ANOVA; significant differences were obtained with the post hoc Fisher's multiple test comparison $(a=0.05)$. All analyses were performed with Statistic $8.0^{\circledR}$ software (StatSoft, Tulsa, USA). Significant differences were set at $p<$ 0.05 .

\section{RESULTS AND DISCUSSION}

\section{Primer specificity and amplification efficiency}

The RT-qPCR assays had amplification efficiencies between $95 \%$ and $99 \%$. The determination correlation coefficients $\left(R^{2}\right)$ values were higher than 0.98 (Table 1). The presence of one peak in the melting curves was the criteri- on to assess the primer specificity. For all evaluated genes, no primer-dimer was detectable, confirming gene-specific amplification (Fig. 1). Also, the specific amplification was corroborated by agarose gel electrophoresis, for all expected PCR products, a single band had been observed. $C t$ values were distributed as indicated for condition 1: 21-26 (28s-rR$N A$ ); 23.11-26 ( $\beta$-tub); 22-26 (ef-1a); 23-30 (gapdh); 23-30 (act) (Fig. 2a ); and for condition 2: 20-27 (28S RNAr); 22-34 ( $\beta$-tub); 22-27 (ef-1a); 23-29 (gapdh); 23-31 (act) (Fig. 2b). However, for expression stability evaluation, a simple comparison of the raw $\mathrm{Ct}$ values for the candidate reference genes could not provide sufficient information. Thus, the following analysis was important for reference gene validation.

Quantitative gene expression analysis is reliable only when suitable reference genes are used for normalization. In this work, we demonstrate varied expression stabilities of five reference genes in Pacific oyster $C$. gigas spat stage during in vitro exposure to two species of toxic dinoflagellates, G. catenatum and $P$. lima in mixed or alone diets and compared to non-toxic diet (I.galbana), and thus highlighted the need to evaluate expression stability of reference genes for normalization.
Figure 1. Specificity of five reference genes of Crassostrea gigas with single peaks in melting curves. (a) $\beta$ tubulin ( $\beta$ tub), (b) a subunit of elongation factor 1 (ef1- $a)$, (c) actin (act), (d) glyceraldehyde-3-phosphate dehydrogenase (gapdh) and (e) 285 ribosomal RNA (28S rRNA).

Figura 1. Especificidad de cinco genes de referencia de Crassostrea gigas con un solo pico en las curvas de fusión. (a) $\beta$ tubulina ( $\beta$ tub), (b) subunidad a del factor de elongación 1 (ef1-a), (c) actina (act), (d) gliceraldehído3-fosfato deshidrogenasa (gapdh) y (e) $28 \mathrm{~S} \mathrm{del}$ ARN ribosomal (ARNr 28S).
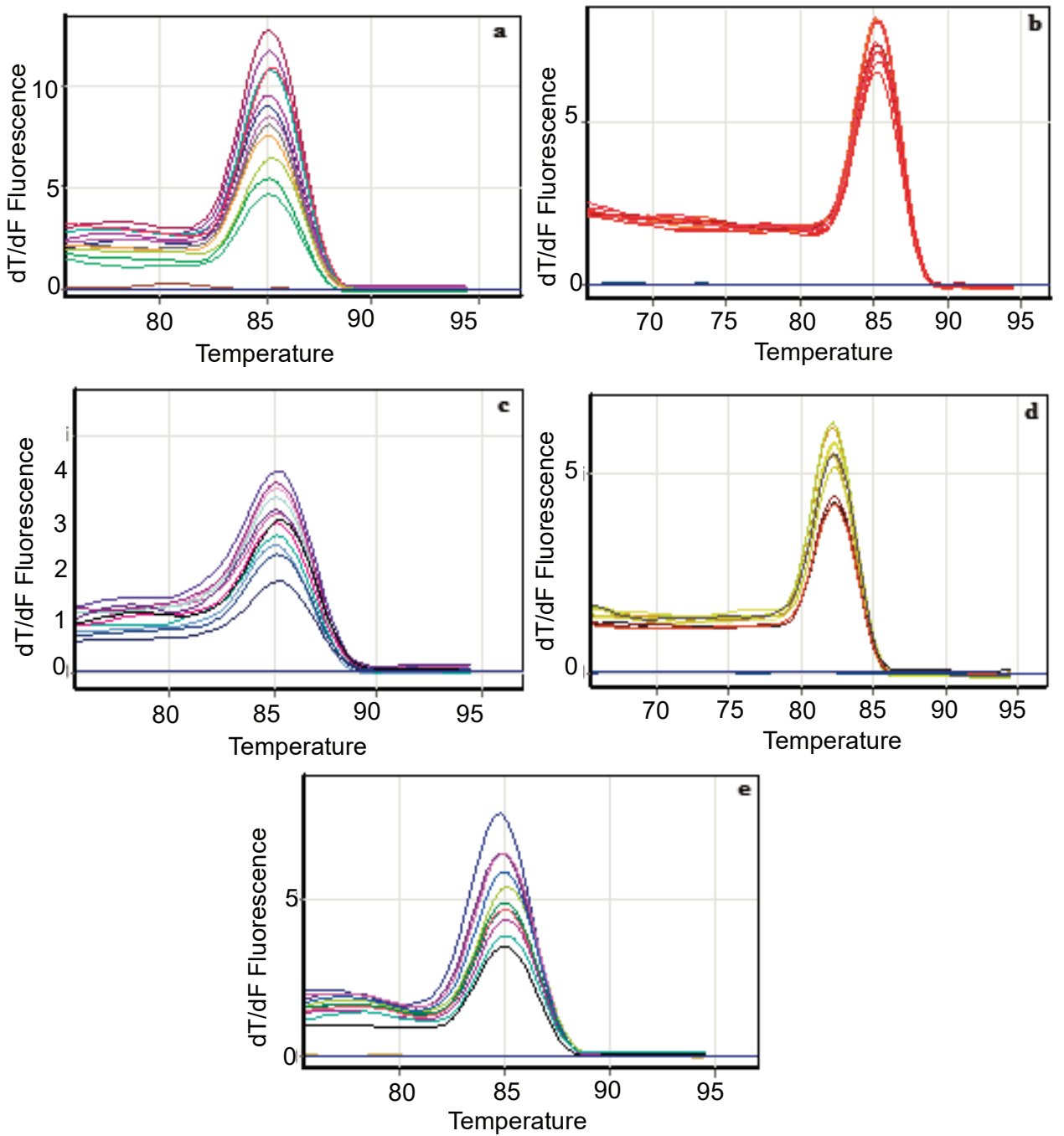

Volumen XXII, Número 2 


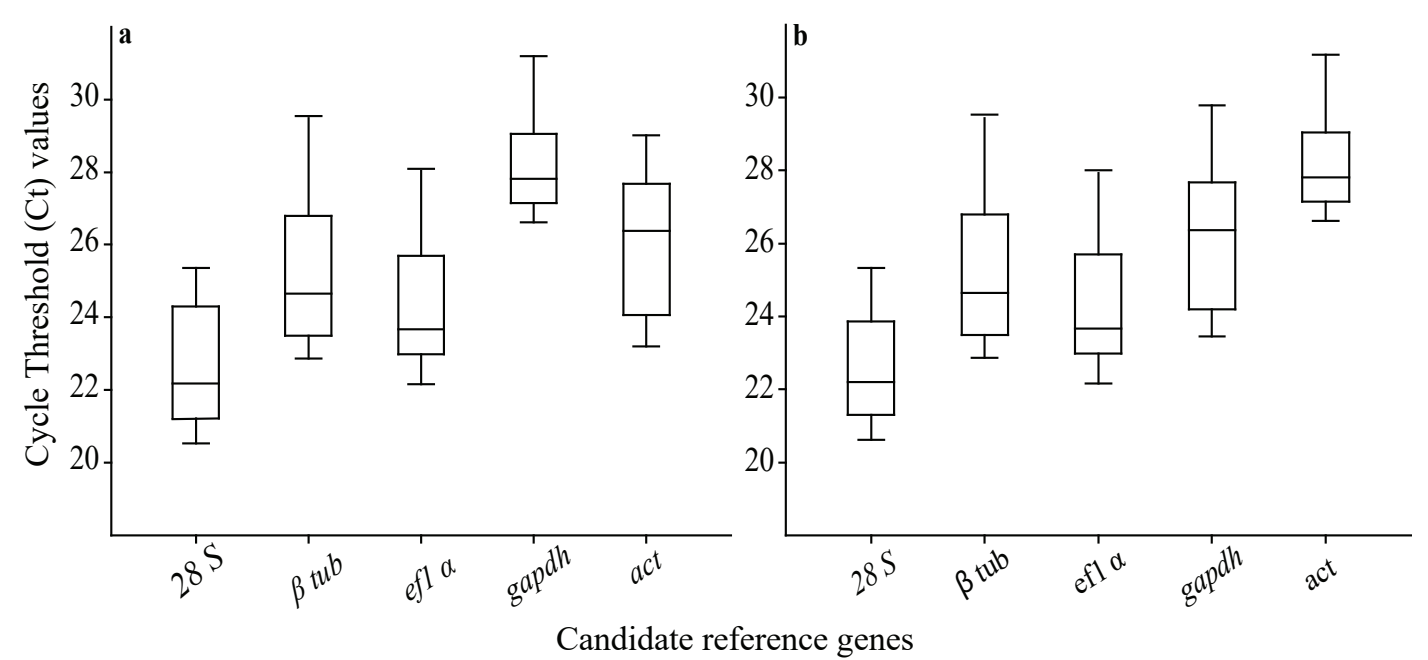

Figure 2. The threshold cycle values of the candidate reference genes. Algal mix Prorocentrum lima and Isochrysis galbana (a) algal mix Gymnodinium catenatum and Isochrysis galbana (b). Lines across the Box plot graph of Ct value represent the median values. Lower and upper boxes show the $25^{\text {th }}$ percentile to the $75^{\text {th }}$ percentile. Whiskers represent the maximum and minimum values.

Figura 2. Valores del ciclo umbral de los genes de referencia candidatos. Dieta mezclada de las algas Prorocentrum lima e Isochrysis galbana (a) dieta mezclada de las algas Gymnodinium catenatum e Isochrysis galbana (b). Las líneas del diagrama de caja de los valores Ct representan los valores medios. Los cuadros inferior y superior muestran el percentil 25 al percentil 75. Los bigotes representan los valores máximos y mínimos.

\section{Evaluation of candidate reference genes}

The $\mathrm{qPCR}$ is considered to be an effective and accurate technique used to examine gene transcription patterns in different experimental conditions. To normalize the expression of the target genes, a reference gene is required, as well as to integrate experimental variations (Livak and Schmittgen, 2001; Bustin and Nolan, 2004). Thus, studying the expression stability of these genes is recommended before quantifying genes of interest (Vandesompele et al., 2002; Bustin and Nolan, 2004). Programs such as GeNorm, NormFinder, and BestKeeper have been successfully employed to determine the stability and identify the most suitable reference gene (Bustin, 2010). However, the use of a single validated gene is common in the qPCR normalization in bivalves (Volland et al., 2017). Due to some reported reference genes can vary transcriptionally under different biological and experimental factors (Mello et al., 2012; Feng et al., 2013), the appropriate selection of reference genes is essential to avoid false-positive results that may lead to misinterpretations and imprecise conclusions (Nascimento et al., 2015).

The order of stability of genes showed by GeNorm analysis was ef-1a, $\beta$-tub, act, gapdh, and 285 rRNA (Fig. 3a) in condition 1. GeNorm software generates the pairwise variation $V$ value $(V n / V n+1)$ with 0.150 cut-off value proposed. The addition a reference gene is not required below the cut-off. The V2/3 and V3/4 values were 0.05 and 0.085 (Fig. $3 b)$, respectively. The results of the analysis suggested three housekeeping genes as normalization factors.

GeNorm analysis showed that gapdh and 285 rRNA genes were the most stable (Fig. 3c) in diets of condition 2. The optimal number of genes required for accurate normalization was two. The V2/3 value was 0.11 ; this value did not increase significantly by incorporating the third gene, so the addition of a third reference gene was not necessary. The expression analyses showed that included two or three internal genes; the values did not change significantly $(p=0.05)$ (Fig. 3d).

The stability analysis with NormFinder was consistent with GeNorm, where the best combination was also 28S rRNA and gapdh for condition 2 data (Table 2a). The results with NormFinder showed that the best combination was the $\beta$-tub and act gene in the mixed diet with $P$. lima $\left(3 \times 10^{3}\right.$ cell $\left.\mathrm{mL}^{-1}\right)$ condition 1 (Table 2b). These results were consistent partially with GeNorm only for $\beta$-tub gene. NormFinder showed the act gene as the second most stable, whereas in the GeNorm analysis, this gene was the third most stable. Therefore, act was regarded as the third gene to be added for the relative expression analysis to data.

The BestKeeper index showed that the most stable genes were ef- $1 a$ and $\beta$-tub, for condition 1 data (Table 3a), which are inconsistent with GeNorm and NormFinder. This analysis also showed that the gapdh gene was the third most stable, thus agreeing with GeNorm. Consequently, we decided to use the two most stable genes showed by GeNorm and NormFinder to perform the reference gene validation for relative expression analysis for this condition. The BestKeeper index agreement with GeNorm and NormFinder, where $\beta$-tub was the most stable gene for condition 1 data (Table 3b).

Our results suggest that $\beta$-tub/ef- 1 a represents a solid combination of internal controls for qRT-PCR normalization in the Pacific oyster spat stage exposed to toxic Prorocentrum lima and combination of $28 \mathrm{~S} r R N A / g a p d h$ represent the most reliable internal controls for oysters exposed to toxic Gymnodinium catenatum. Based on our results, we recommend the use of this combination of reference genes for the experimental conditions 1 and 2 (Fig. 3). 
Table 2. NormFinder stability values for reference genes. An ideal reference gene has inter-group variation as close to zero. Crassostrea gigas exposure to mixed diet of Gymnodinium catenatum and Isochrysis galbana (a), mixed diet of Prorocentrum lima and Isochrysis galbana (b).

Tabla 2. Valores de estabilidad NormFinder para los genes de referencia. Un gen de referencia ideal tiene una variación entre grupos lo más cercano a cero. Exposición de Crassostrea gigas a una dieta mezclada de Isochrysis galbana y Gymnodinium catenatum (a) y una dieta mezclada de Isochrysis galbana y Prorocentrum lima (b).

\begin{tabular}{lll}
\hline Gene name & \multicolumn{2}{c}{$\begin{array}{c}\text { NormFinder Stability Value ( } \boldsymbol{p} \text { ) } \\
\text { Intergroup variation }\end{array}$} \\
\hline $28 \mathrm{~S}$ & (a) & (b) \\
\hline$\beta$ tub & 0.012 & 0.012 \\
ef1 a & $0.011^{*}$ & $0.007^{*}$ \\
gapdh & 0.014 & 0.009 \\
act & $0.008^{*}$ & $0.010^{*}$ \\
\hline Best pair & 0.013 & $0.008^{*}$ \\
\hline
\end{tabular}

Stability value for best combination of two genes (best pair). ${ }^{*}$ Best combination of two genes

Table 3. Correlation coefficient with the BestKeeper index of Crassostrea gigas fed with mixed diet Gymnodinium catenatum and Isochrysis galbana (a) Prorocentrum lima and Isochrysis galbana (b).

Tabla 3. Coeficiente de correlación con el índice BestKeeper de Crassostrea gigas alimentado con una dieta mezclada de Gymnodinium catenatum e Isochrysis galbana (a) y una dieta mezclada de Prorocentrum lima e Isochrysis galbana (b).

\begin{tabular}{lccccc}
\hline Gene name & 28S & $\boldsymbol{\beta}$ tub & ef1 $\boldsymbol{\alpha}$ & Gapdh & Act \\
\hline $\begin{array}{l}\text { (a) Coefficient of } \\
\text { Correlation }(r)\end{array}$ & 0.86 & $0.98^{*}$ & $0.99^{*}$ & $0.96^{*}$ & 0.93 \\
$\begin{array}{l}\text { (b) Coefficient of } \\
\text { Correlation }(r)\end{array}$ & $0.89^{*}$ & $0.978^{*}$ & 0.86 & $0.94^{*}$ & 0.88 \\
$p$ Value & 0.001 & 0.001 & 0.001 & 0.001 & 0.001 \\
\hline
\end{tabular}

The coefficient of correlation $(r)$ and the $p$-value measure the correlation between each gene and the BestKeeper index. *Most stable Genes

In bivalves mollusk, several genes including ef- $1 a$, act, $\beta$-tub, 28S rRNA and gapdh are frequently used as reference genes for qPCR analysis, under exposure to marine toxins in experimental conditions (Mello et al., 2012; Feng et al., 2013; Volland et al., 2017; Martínez-Escauriaza et al., 2018). In our study, these five available candidate reference genes were selected, and their expression was monitored to revise their stability by real time quantitative PCR during in vitro exposure of $C$. gigas spat to the toxic dinoflagellates. The selected reference genes are involved in ribosomal metabolism (285 $r R N A)$, cytoskeleton structure (act, $\beta$-tub), catalyzation in glycolysis (gapdh), and elongation process in protein synthesis $(e f-1 a)$. The three algorithms allowed ranked candidate reference genes according to their expression stability, showing agreement in the results (Fig. 3). The analysis provided a consensus among the three algorithms in samples of the first condition where the $\beta$-tub gene appeared as the most suitable reference gene by NormFinder; the second most stable observed was ef- $1 a$ gene by GeNorm, act gene by NormFinder, and gapdh; the third more stable gene was act, which is commonly used as an internal standard for the normalization of gene expression (Fig. 3). GeNorm and NormFinder also showed approaches concordant in samples of the second condition indicating the pair $28 \mathrm{~S}$ rRNA/gapdh as the best combination of reference genes (Fig. 3).

$E f-1 a$ is a eukaryotic translational elongation factor, which plays a key role in protein translation (Browne and Proud, 2002; Ejiri, 2002). It has been reported the use of ef$1 a$ gene as the best reference gene in soft-shell clams, $M$. arenaria (Siah et al., 2008), as well as an internal control in studies of OsHV-1 infection in adult oysters (Renault et al., 2011). However, it is not suitable for use in oyster larvae (Du et al., 2013). In this study, ef-1a was one of the most stable genes, so it was used as a reference gene in the oysters spat exposed to $G$. catenatum.

The $\beta$-tub and act gene coding for cytoskeletal proteins, which are involved in structure playing a pivotal role in phagocytosis and encapsulation (Martin et al., 2010). In fact, $\beta$-tub has been used extensively as a reference standard, encloses recent studies in oysters (Zhang et al., 2011). We found this gene as one of the most stable, so it was used as a reference gene under our experimental condition (Condition $1)$.

In mollusks studies, act gene has been frequently used in RT-qPCR assays (Martin et al., 2010; Zhang et al., 2011; Du et

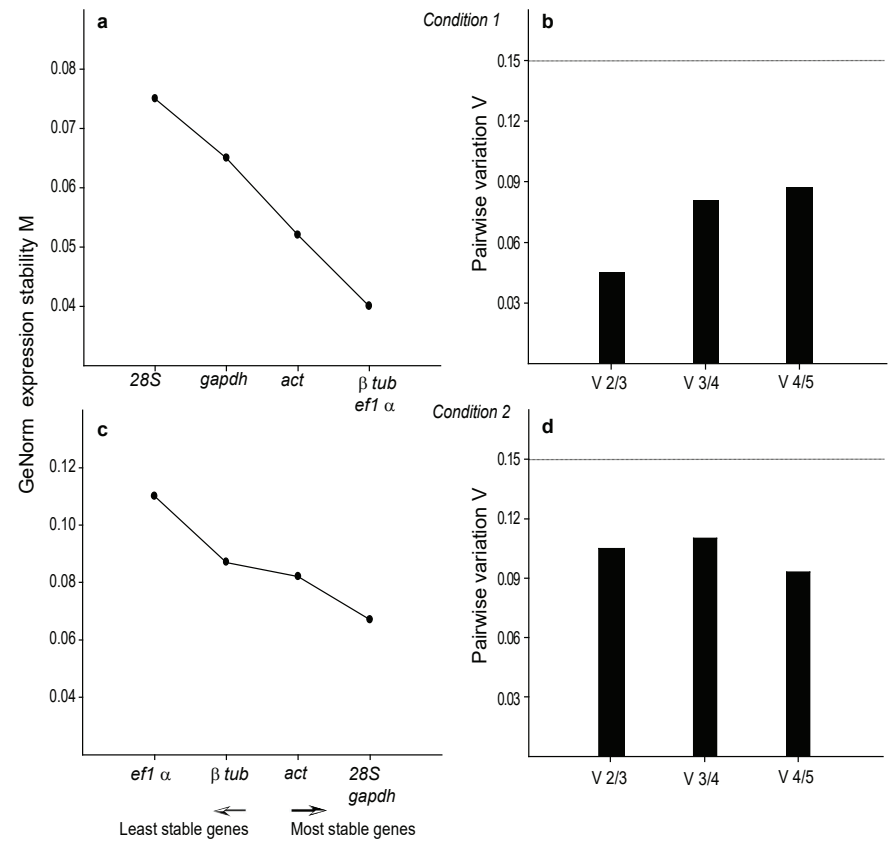

Figure 3. Gene expression stability (M) calculated by GeNorm software and pairwise variation analysis in oysters exposed to algal mix of Prorocentrum lima and Isochrysis galbana (a, b), algal mix of Gymnodinium catenatum and Isochrysis galbana (c, d). Bar values indicate change magnitude in the normalization factor after the inclusion of an additional reference gene. Figura 3. Estabilidad de la expresión génica (M) calculada por el software GeNorm y análisis de variación por pares en ostiones expuestos a una dieta mezclada de las algas de Prorocentrum lima e Isochrysis galbana $(a, b)$ y una dieta mezclada de las algas de Gymnodinium catenatum e Isochrysis galba$n a(c, d)$. Los valores de la barra indican la magnitud del cambio en el factor de normalización después de la inclusión de un gen de referencia adicional. 
al., 2013; Martínez-Escauriaza et al., 2018). The findings of the present work showed changes in the expression level of the act gene for the presence of both species of toxic dinoflagellates, which suggest act is an unstable gene.

The 28S rRNA gene, is chosen extensively as a reference gene and frequently is used in mollusks bivalves (Cellura et al., 2007; Zhang et al., 2011; Volland et al., 2017). The 28S rRNA has been reported as an unstable gene when hemocytes of soft-shell clams, M. arenaria, were challenged with Vibrio splendidus (Araya et al., 2008). However, we found this gene as one of the most stable, so it was used as a reference gene under our experimental condition (Condition 2).

The gapdh gene is frequently used as a reference gene in humans, plants, and invertebrates such bivalves; it has also been a choice for normalization in experimental approaches of bivalve tissues such as gills, digestive gland (Sussarellu et al., 2012; Martínez-Escauriaza et al., 2018). This gene expression was stable in our experiment only for condition 2, so it was suitable for the reference genes.

It has been widely reported the use of ef- $1 a, a c t, \beta-t u b$, 185, 28S, and gapdh genes as references genes in bivalves as Ostrea edulis (Feng et al., 2013), scallops (Morga et al., 2010), Mytilus spp. or C. gigas in both experimental and field studies (Nuñez-Acuña et al., 2013; Della Torre et al., 2013; Lacroix et al., 2014), clam Ruditapes philippinarum (Volland et al., 2017) oysters Crassostrea sikamea and Crassostrea angulate (Yang et al., 2017) and Mytilus galloprovincialis (Martínez-Escauriaza et al., 2018) both in tissues (gonads, gills, and digestive gland) and hemocyte. However, Du et al. (2013), reports that none of these five common reference genes were stables due to their high variability with the experimental conditions tested, suggesting they were unsuitable as internal controls. However, our results confirmed that traditional reference genes commonly used, such as $\beta$-tub, ef-1a, $28 S$ rRNA, and gapdh showed the highest stability, when oysters spat were exposed to toxic dinoflagellates (condition 1 and 2).

\section{Reference gene validation to normalize gene expression}

To evaluate the suitability and performance of the reference genes established by the three software tools, the expressions of trypsin (tryp) and cytochrome $\mathrm{C}$ oxidase (COI) genes in oysters after challenge with the two toxic dinoflagellate species and compared with a calibrator (nontoxic control group) were measured. By relative $\mathrm{qPCR}$, the expression pattern of target genes was evaluated. For normalization, the reference genes selected for each condition were used. From the three software, the most stable reference genes selected had a correlation coefficient of R2>0.98 (Table 1). Based on our experiments, $\beta$-tub and ef- $1 \mathrm{a}$ were the most stable reference genes for the Pacific oyster spat stage exposed to toxic P. lima. On another hand, $28 \mathrm{~S} r R N A$ and gapdh were the most stable reference genes for Pacific oyster spat exposed to toxic $G$. catenatum. Therefore, the combined use of these genes was utilized as internal controls for accurate normalization of qPCR. Expression profiles of tryp and coi vary substantially between normalization strategies. These genes were affected by exposure to the toxic dinoflagellates; we found significant differences in the expression levels of genes in oysters challenged in both conditions $(p<0.05)$ compared with oysters fed with the non-toxic control (Fig. 4).

Expression profiles of tryp and coi genes vary substantially between normalization strategies (Fig. 4). The results of this work point out to validate the reference candidate genes for different experimental conditions; also, we suggest to applied a minimum of two statistical algorithms. It is recommended to perform a complete analysis with the conditions tested in C. gigas adults and in different tissues to evaluate the level of expression by tissue, due to the expression of reported reference genes changes under experimental conditions.

\section{CONCLUSIONS}

Based on the results, we recommend the combination of $\beta$-tub and ef- $1 a$ as reference genes for the normalization in Crassostrea gigas fed a mixed diet of I. galbana and P. lima, whereas $28 S$ rRNA and gapdh was best for oysters fed with $I$. galbana and G. catenatum. The combined use of these genes as optimal reference genes will be useful for data normalizing when studying expression levels in oysters spat stage exposed to these dinoflagellates, providing more reliable and accurate expression measurements, to improve the current knowledge about the effect of dinoflagellate DPS and PSP toxins producers on the Pacific oyster C. gigas. Additionally, were demonstrated the relevance of evaluating the stability of reference genes statistically because each experimental condition used to change the gene expression.

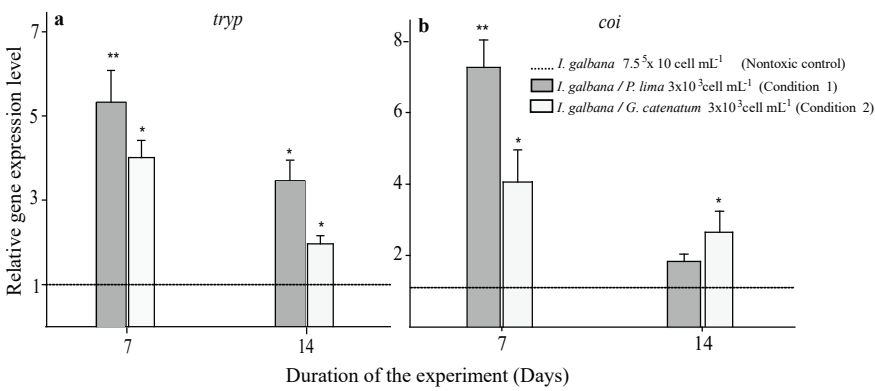

Figure 4. Relative expression of tryp (a) and coi (b) using selected reference genes $\beta$ tub and ef1a (condition 1); 28S rRNA and gapdh (condition 2). The bars represent standard error. The asterisks mean significant differences between treatment and control group ( $p<0.05$ in Fisher's LSD).

Figura 4. Expresión relativa de tryp (a) y coi (b) usando los genes de referencia seleccionados $\beta$ tub y ef1a (condición 1); ARNr 285 y gapdh (condición 2). Las barras representan el error estándar. Los asteriscos significan diferencias significativas entre el grupo control y los tratamientos $(p<0.05$ en LSD de Fisher).

\section{REFERENCES}

Andersen, C.L., Jensen, J.L., Orntoft, T.F. 2004. Normalization of real-time quantitative reverse transcription-PCR data: a model-based variance estimation approach to identify genes suited for normalization, applied to bladder and colon cancer data sets. Cancer Research. 64:5245-5250.

Araya, M.T., Siah, A., Mateo, D., Markham, F., McKenna, P., Johnson, G. 2008. Selection and evaluation of housekeeping 
genes for haemocytes of soft-shell clams (Mya arenaria) challenged with Vibrio splendidus. Journal Invertebrate Pathology. 99:326-331.

Band-Schmitd, C.J., Bustillos-Guzmán, J., Gárate-Lizárraga, I., Lechuga-Devéze, CH., Reinhart, K. 2005. Paralytic shellfish toxin profile in strains of dinoflagellate Gymnodinium catenatum Graham and the scallop Argopecten ventricosus G-B. Sowerby II from Bahia Concepción. Gulf of California México. Harmful Algae. 4:21-31.

Bustin, S.A. 2002. Quantification of mRNA using real-time reverse transcription PCR (RT-PCR): trends and problems. Journal of Molecular Endocrinology. 29:23-39.

Bustin, S.A., Nolan, T. 2004. Pitfalls of quantitative real-time reverse-transcription polymerase chain reaction. Journal of Biomolecular Technology. 15:155-66.

Bustin, S.A., Benes, V., Nolan, T., Pfaffl, M.W. 2005. Quantitative real-time RT-PCR-a perspective. Journal of Molecular Endocrinology. 34:597-601.

Bustin, S.A. 2010. Why the need for qPCR publication guidelines? -The case for MIQE. Method. 50: 217-226.

Browne, G.J., Proud, C.G. 2002. Regulation of peptide-chain elongation in mammalian cells. European Journal Biochemistry. 269:5360-5368.

Cellura, C., Toubiana, M., Parrinello, N., Roch, P. 2007. Specific expression of antimicrobial peptide and HSP70 genes in response to heat-shock and several bacterial challenges in mussels. Fish Shellfish Immunology. 22:340-350.

Della Torre, C., Bocci, E., Focardi, S.E., Corsi, I. 2013. Differential $A B C B$ and $A B C C$ gene expression and efflux activities in gills and haemocytes of Mytilus galloprovincialis and their involvement in cadmium response. Marine Environmental Research. 93:1-8.

Dheda, K., Huggett, J.F., Chang, J.S., Kim, L.U., Bustin, S.A., Johnson, M.A. 2005. The implications of using an inappropriate reference gene for real-time reverse transcription PCR data normalization. Anal Biochem. 344:141-143.

Dheilly, N.M., Lelong, C., Huvet, A., Favrel, P. 2011. Development of a Pacific oyster (Crassostrea gigas) 31,918-feature microarray: identification of reference genes and tissueenriched expression patterns. BMC Genomics. 12:468-77.

Du, Y., Zhang, L., Xu, F., Huang, B., Zhang, G., Li, L. 2013. Validation of housekeeping genes as internal controls for studying gene expression during Pacific oyster (Crassostrea gigas) development by quantitative real-time PCR. Fish Shellfish Immunology. 34:939-945.

Ejiri, S. 2002. Moonlighting functions of polypeptide elongation factor 1: from actin bundling to zinc finger protein R1associated nuclear localization. Bioscience Biotechnology. 66:1-21.

Feng, L., Yu, Q., Li, X., Ning, X., Wang, J., Zou, J. 2013. Identification of Reference Genes for qRT-PCR Analysis in Yesso Scallop Patinopecten yessoensis. PLoS ONE. https://doi.org/10.1371/ journal.pone.0075609

Guillard, R.R. 1975. In: Smith WL and Chanley MH (Eds) Culture of marine invertebrate animals, Plenum Press, New York.

Gifford, D.J., Caron, D.A. 2000. In: Harris RP et al. (Eds) ICES Zooplankton methodology manual. Academic Press, London.

García-Lagunas, N., Romero-Geraldo, R., Hernández-Saavedra, N.Y. 2013. Genomics study of the exposure effect of Gymnodinium catenatum, a paralyzing toxin producer, on
Crassostrea gigas defense system and detoxification genes. PLoS ONE. https://doi.org/10.1371/journal.pone.0072323

Hallegraeff, G.M. 1995. In: Manual on Harmful Marine Microalgae. Hallegraeff GM, Anderson DM, Cembella AD (Eds) IOC Manuals and Guides No. 33, UNESCO. Paris, France.

Helm, M.M. 2004. Hatchery culture of bivalves. A practical manual. FAO. Fisheries Technical Paper.

Kodama, M. 2010. Paralytic shellfish poisoning toxins: Biochemistry and Origin. ABSM 3:1-38.

Lacroix, C., Coquillé, V., Guyomarch, J., Auffret, M., Moraga, D. 2014. A selection of reference genes and early-warning mRNA biomarkers for environmental monitoring using Mytilus spp. as sentinel species. Marine pollution bulletin. 86:304-313.

Livak, K.J., Schmittgen, T.D. 2001. Analysis of relative gene expression data using real-time quantitative PCR and the 2- $\Delta \Delta$ CT Method. Methods. 25:402-408.

Martin, C.A., Gelbart, M., Fernandez-Gonzalez, R., Kaschube, M., Wieschaus, E.F. 2010 Integration of contractile forces during tissue invagination. The Journal of Cell Biology. 188:735-739.

Martínez-Escauriaza, R., Lozano, V., Pérez-Parallé, M.L., Pazos, A.J., Sanchez, J.L. 2018 Validation of reference genes in mussel Mytillus galloprovincialis tissues under the presence of okadaic acid. Journal Shellfish Research. 37:93-101.

Morga, B., Arzul, I., Faury, N., Renault, T. 2010. Identification of genes from flat oyster Ostrea edulis as suitable housekeeping genes for quantitative real time PCR. Fish \& Shellfish Immunology. 29:937-945.

Mello, D.F., De Oliveira, E.S., Vieira, R.C., Simoes, E., Trevisan, R., Dafre, A.L., Barracco, M.A. 2012. Cellular and transcriptional responses of Crassostrea gigas hemocytes exposed in vibrio to brevetoxin (PbTx-2). Marine Drugs. 10:583-597.

Nascimento, C.S., Barbosa, L.T., Brito, C., Fernandes, R.P.M., Mann, R.S., Pinto, A.P.G., Oliveira, C.H., Dodson, V.M., Guimaraes, F.E.S., Duarte, S.M. 2015. Identification of suitable reference genes for real time quantitative polymerase chain reaction assays on pectoralis major muscle in chicken (Gallus gallus). PLoS ONE. https://doi.org/10.1371/journal.pone.0127935

Núñez-Vázquez, E., Heredia-Tapia, A., Pérez-Urbiola, J., AlonsoRodríguez, R., Arellano-Blanco, J., Cordero-Tapia, A., PérezLinares, J., Ochoa, J.L. 2003. Evaluation of dinoflagellate toxicity implicated in recent $\mathrm{HAB}$ events in the Gulf of California, México. In: Holland P, Rhodes L, Brown L (eds) Proceedings from HABTech. Workshop, APEC. Nelson, New Zealand. No. 906.

Nuñez-Acuña, G., Aballay, A.E., Hégaret, H., Astuya, P.A., Gallardo-Escárate, C. 2013. Transcriptional responses of Mytilus chilensis exposed in vivo to saxitoxin (STX). Journal of Molluscan Studies. 79:323-331.

Pfaffl, M.W., Tichopad, A., Prgomet, C., Neuvians, T.P. 2004. Determination of stable housekeeping genes, differentially regulated target genes and sample integrity: BestKeeperExcel-based tool using pair-wise correlations. Biotechnology Letters. 26:509-515.

Renault, T., Faury, N., Barbosa-Solomieu, V., Moreau, K. 2011. Suppression substractive hybridisation (SSH) and real time $P C R$ reveal differential gene expression in the Pacific cupped oyster, Crassostrea gigas, challenged with Ostreid herpesvirus 1. Development Comparative Immunology. 35:725-735.

Rozen, S., Skaletsky, H. 2000. In: Krawetz S, Misener S (eds) Bioinformatics Methods and Protocols: Methods in Molecular Biology. Humana Press. Totowa, NJ.

Volumen XXII, Número 2 
Saavedra, C., Bachére, E. 2006. Bivalve genomics. Aquaculture. 256:1-14.

Siah, A., Dohoo, C., Mckenna, P., Delaporte, M., Berthe, F.C.J. 2008. Selecting a set of housekeeping genes for quantitative realtime PCR in normal and tetraploid haemocytes of soft-shell clams, Mya arenaria. Fish Shellfish Immunology. 25:202-207.

Sussarellu, R., Fabioux, C., Camacho-Sanchez, M., Le Goïc, N., Lambert, C., Soudant, P., Moraga, D. 2012. Molecular and cellular response to short-term oxygen variations in the Pacific oyster Crassostrea gigas. Journal Experimental Marine Biology and Ecology. 412:87-95.

Shumway, S.E. 1990. A review of the effects of algal blooms on shellfish and aquaculture. Journal World Aquaculture Society. 21:65-104.

Vandesompele, J., De Preter, K., Pattyn, F., Poppe, B., Van, R.N. 2002. Accurate normalization of real-time quantitative RT-PCR data by geometric averaging of multiple internal control genes. Genome Biology. 3:1-12.
Volland, M., Blasco, J., Hampel, M. 2017. Validation of reference genes for RT-qPCR in marine bivalve ecotoxicology: Systematic review and case study using copper treated primary Ruditapes philippinarum hemocytes. Aquatic Toxicolgy. 185:86-94.

Yan, L., Su, J., Wang, Z., Yan, X., Yu, R. 2017. Selection of reference genes for expression analysis of Kumamoto and Portuguese oysters and their hybrid. Journal Ocean University China. 16:1139-1147.

Zhang, Y., He, X., Yu, Z. 2011. Two homologues of inhibitor of NF-kappa B (IkB) are involved in the immune defense of the Pacific oyster, Crassostrea gigas. Fish Shellfish Immunology. 30:1354-1361. 